\title{
Sports after Busy Work: Work-Related Cognitive Failure Corresponds to Risk Bearing Behaviors and Athletic Injury
}

\section{Deporte después de una jornada laboral ajetreada: los fallos cognitivos en el trabajo se relacionan con comportamientos arriesgados y con sufrir lesiones atléticas}

\author{
Achim Elfering, Simone Grebner, Lynn Schwander, \& Mirjam Wattinger \\ University of Bern, Switzerland
}

Disponible online 30 de abril de 2014

\begin{abstract}
Although employees are encouraged to take exercise after work to keep physically fit, they should not suffer injury. Some sports injuries that occur after work appear to be work-related and preventable. This study investigated whether cognitive failure mediates the influence of mental work demands and conscientiousness on risk-taking and risky and unaware behaviour during after-work sports activities. Participants were 129 employees (36\% female) who regularly took part in team sports after work. A structural equation model showed that work-related cognitive failure significantly mediated the influence of mental work demands on risky behaviour during sports $(\mathrm{p}<.05)$ and also mediated the directional link between conscientiousness and risky behaviour during sports $(\mathrm{p}<.05)$. A path from risky behaviour during sports to sports injuries in the last four weeks was also significant $(\mathrm{p}<.05)$. Performance constraints, time pressure, and task uncertainty are likely to increase cognitive load and thereby boost cognitive failures both during work and sports activities after work. Some sports injuries after work could be prevented by addressing the issue of work redesign.
\end{abstract}

Keywords: Sport; Occupational Stress; Sports Injuries; Prevention.

Generalmente se anima a los trabajadores a realizar ejercicio después de su jornada laboral para que se mantengan en buena forma física, no obstante, debe evitarse que se lesionen. Las lesiones deportivas que ocurren después de la jornada laboral parecen estar en parte relacionadas con el trabajo y se pueden prevenir. Este estudio examina si los fallos cognitivos median la influencia que ejercen las exigencias mentales laborales y la responsabilidad sobre la asunción de riesgos y el comportamiento imprudente e inconsciente durante la práctica de deporte después del trabajo. Los participantes en el estudio fueron 129 empleados ( $36 \%$ mujeres) que realizaban regularmente deportes de equipo después del trabajo. En un modelo de ecuaciones estructurales, los fallos cognitivos en el trabajo mediaron significativamente la influencia que las exigencias mentales laborales ejercían sobre el comportamiento arriesgado en los deportes $(\mathrm{p}<.05)$. A la vez, los fallos cognitivos en el trabajo también mediaron la relación entre la responsabilidad y el comportamiento arriesgado en los deportes $(\mathrm{p}<.05)$. Por otra parte, la asociación entre comportamiento arriesgado y lesiones deportivas acontecidas durante las últimas cuatro semanas también fue significativa $(\mathrm{p}<.05)$. Las restricciones, la presión temporal y la incertidumbre en las tareas a realizar, son factores del entorno laboral que probablemente aumentan la carga cognitiva y en consecuencia promueven la aparición de fallos cognitivos durante el trabajo y el deporte posterior. Por tanto, la prevención de las lesiones deportivas después del trabajo debería incluir la adopción de medidas en el entorno laboral.

Palabras clave: Deporte; Estrés Ocupacional; Lesiones Deportivas; Prevención.

Correspondence concerning this article should be addressed to: Prof. Dr. Achim Elfering, University of Berne, Institute of Psychology, Department for Work and Organizational Psychology, Fabrikstrasse 8, 3012 Bern, Switzerland. E-mail: achim.elfering@psy.unibe.ch Telephone: +41 (0) 31 - 631 36 39, Telefax: +41 (0) $31-6318212$ 
For the year 2009 the Swiss bureau of accident prevention reported 315,000 sport injuries (BFU, 2011). While primary prevention of traffic accidents contributed to decreasing mortality numbers in Switzerland during the last ten years, the number of sport injuries has increased in the same period (BFU, 2011). Efforts toward prevention of sport injury should therefore be increased and address physical and biomechanical risk factors by developing, for example, better sport equipment, and considering psychological factors such as impeded risk perception and lack of attention (Junge, 2000; Rümmele, 1989).

This study investigated potential psychological risk factors that are work related and might increase the risk of injury during sports activities after work. Sport-promoted recovery after mentally demanding was best when subsequent sport activity did not put further strain on those cognitive functions that were strained at work and drain those resources that were already depleted at work. Instead, in order to recover, it was best to do a very different activity, one that would refresh those same resources (Semmer, Grebner \& Elfering, 2010). Thus, after mentally demanding work, motor activity was beneficial for enabling detachment from work (Sonnentag \& Jelden, 2009). In doing sports after work, mental capacities are given a break in order to recover. At the end of work, cognitive resources that can be spent in action regulation were depleted, and depletion of resources for self-regulation often corresponded to less engagement in sport activities after work (Choi et al., 2010; Kouvonen et al., 2005; Sonnentag \& Jelden, 2009; Tsutsumi et al., 2003). Recently, in a sample size of up to 170,000 men and women, a large-scale meta-analytic study confirmed the tendency for high-stress workers to participate less in physical fitness activities and sports (IPD-Work Consortium, Fransson et al., 2012). The consequences of physical inactivity after work are not restricted to poor recovery from work, but sedentary activity after work is also associated with poorer health (with musculoskeletal complaints, for instance: see Hildebrandt, Bongers, Dul, van Dijk \& Kemper, 2000). Activity after work is therefore generally beneficial (Semmer et al., 2010) but may bear some risk, too: after work, switching off mentally during sports may increase risk of injury, especially in complex team sports. For instance, lack of attention to other players may cause sport accidents (Rümmele, 1989). When starting sports after a demanding work day with the help of routines, resources are still depleted and action regulation is presumably based on more basic automatic resource-saving regulation modes. In these more automatic modes of action regulation, the risk of cognitive failures increases, attention to others decreases and finally - in complex environments like team sports - the risk of injury increases (Hacker, 2003; Nitsch, 2004). Consequently, the risk of injury in team sports after work should be higher in those who hold mentally demanding jobs.

\section{Mental Work Load, Sport Accidents and Injuries}

The theoretical background of the research question included models of stress-related sport injury (Andersen \& Williams, 1988), action regulation theory (Hacker, 2003; Nitsch, 2004), and cognitive error modelling (Reason, 1990). The most influential model of stress-related sport injury by Andersen and Williams (1988) characterizes stress to increase injury risk by the many physiological and attentional changes that potentially occur because of stress responses while doing sports including increases in generalized muscle tension, a narrowing of the visual field, and increased distractibility (Andersen \& Williams, 1993, Williams \& Andersen, 2007). Thereby, stressors, e.g. stressful life events often precede sports activities.

Action regulation theory is a general cognitive theory of behaviour mostly applied to behaviour at work (see, for example, Frese \& Zapf, 1994; Hacker, 1998; Oesterreich \& Volpert, 1986) and at sports (Baumann, 1979; Kratzer, 1993; Nitsch, 2004; Seiler, 1995). Action regulation theory assumes that behaviour is goal related. Stress-related task characteristics are classified according to necessities and possibilities of cognitive action regulation. Moreover, conditions which interfere with information processing, and therefore impede goal-directed action, are considered. Such conditions include, for instance, time pressure, interruptions by co-workers and teammates, or unclear instructions from supervisors or trainers. After mentally demanding work when mental resources were depleted (Mulder, Mulder, Meijman, Veldman \& van Roon, 2000) - individuals tended to act in more economic modes of action regulation that were less resource consuming but more stereotypical and automatic, and often neglected full consideration of situational complexity (Semmer et al., 2010). Hofmann and Frese (2011) called errors in such economic action regulation modes "movement errors" (p.11). Movement errors result from wrong psychomotor actions. Typical movement errors include stumbling while using a stairway. Movement errors comprise slips in attention. Movement errors do not occur because of a lack of movement knowledge but are "skill-based" in Reason's (1990) terminology of cognitive errors. Reason called them "slips" and "lapses" that include some "failure to make an attentional check" (p.60) and "failure to monitor the current intention" (p.61). Mentally demanding work conditions increase the risk of such cognitive failure (Elfering, Grebner \& Dudan, 2011; Wallace \& Chen, 2005). Recently, a study on naval accidents showed cognitive failure to mediate the link between stress experience and accidents during routine activities on board (such as knocking against foreign objects and tripping on gangplanks, Day, Brasher \& Bridger, 2012). While the association of life stress and sport injuries is well founded - for instance Williams and Roepke (1993) concluded that individuals with high life event stress were two to five times more likely to be injured than others with low life event stress - to the knowledge of the authors, this study fits for the first time a mediation model 
to empirical data that assumed work-related cognitive failures to mediate the influence of mental work demands on disregardful sport activities within team sports and on athletic injury risk.

\section{Individual Differences in Cognitive Failures}

Cognitive failures covered all types of execution failures and/or storage failures but excluded failures of ability or planning (Broadbent et al., 1982; Klumb, 1995). Early conceptualizations of cognitive failures had seen cognitive failure merely as a consequence of stable individual differences in self-regulation (Broadbent et al., 1982; Reason, 1988). Heritability estimates of cognitive failure around $50 \%$ were reported from a study on monozygotic and dizygotic twins (Boomsma, 1998). Nevertheless, the focus on cognitive failure as a trait was criticized by Wallace and Chen (2005), who intended to develop a cognitive failure scale that is more sensitive to work demands. They especially hypothesised that "simply having too much work to do in the time available" (p. 619) would increase the risk of cognitive failure. Although cognitive failure at work was found to be positively related to work demands, cognitive failure was also related to conscientiousness. Conscientiousness was negatively related to workplace cognitive failure, presumably because "individuals higher on conscientiousness should be more attentive to work tasks and thereby not commit as many cognitive failures" (Wallace \& Chen, 2005, p. 618). Hence, cognitive failures at work seemed to be related both to individual characteristics and to work stressors (Wallace \& Chen, 2005).

The objective of this study was therefore to examine cognitive failures within a mediation model that assumed performance constraints, time pressure at work, and task uncertainty on the one side, and conscientiousness on the other side to correspond to work-related cognitive failures, which in turn lead to carelessness, risky behavior and lack of attention during sports after work. Carelessness, risky behavior and lack of attention to others should correspond to a higher risk of injuries.

Methods
Participants
Participants were employees from three urban areas in
Switzerland. The third and fourth author invited 160 indivi-
duals from their wider circle of acquaintances to participate.
Participants were contacted by phone and asked whether they
were willing to participate. In order to participate, employees
had to work at least $50 \%$ of a full-time work schedule and do
sports after work at least once a week. All participants gave
their informed written consent before a questionnaire was sent
to their private postal address. Participation rate was $100 \%$ and
160 questionnaires were sent by mail. Response rate in this
questionnaire study was $80.6 \%$ (129 questionnaires out of 160
were returned). The majority of participants were men (63.3\%).
Mean age was 30.5 years (SD = 11 years). Most participants

worked full time (85\%). Participants mostly worked in administration and finance (38.8\%), military aviation (21.7\%), hostelry and sales (14\%), sanitary and welfare (10.9\%), and craftsmanship (9.3\%). Seven participants did not report their occupation. Participants had finished an apprenticeship (43\%), finished higher education (29\%), and some held a university degree $(22 \%)$. Most of the participants regularly did team sports after work $(73 \%$, who played ice hockey, soccer, handball, volleyball or unihockey). The others (27\%) engaged in running, jogging, riding, judo, tennis, skating, and fitness training. The study was carried out in accordance with the Code of Ethics of the World Medical Association (Declaration of Helsinki) and has been approved by the Ethics Committee of the University faculty, Bern, Switzerland.

\section{Measures}

Performance constraints, time pressure and uncertainty at work. Work characteristics were measured by a shortened version of the Instrument for Stress-Oriented Task Analysis (ISTA, Version 5.1: Semmer, 1984; Semmer et al., 1995). ISTA scales have been shown to be associated with well-being in a number of studies using different designs and methods of analysis (for example, Elfering, Dubi \& Semmer 2010; Elfering et al., 2005; Elfering, Grebner, Semmer \& Gerber, 2002; Grebner, Semmer \& Elfering, 2005; Grebner et al., 2003; Semmer, Zapf \& Greif, 1996; Sonnentag \& Bayer, 2005). The scale of performance constraints comprised four items that are bipolar in structure by comparing work from two employees: for example, "A has documents and information at his/her disposal, which is always accurate and up to date. $\mathbf{B}$ has documents that often contain incomplete and obsolete information." Participants were asked "Which of the above work activities mostly resembles yours?" with the following response categories: exactly like A (1), rather like A (2), between A and B (3), rather like B (4), exactly like B (5). Reliability was good (Cronbach's alpha $=.74)$.

The ISTA scale on time pressure consisted of the following four items (Cronbach's alpha $=.80)$ : How often are you under time pressure? (1); How often does it happen that you cannot take your break, or that you cannot take your break on time, because of too much work? (2); How often does it happen that you go home late because of too much work? (3); How often does your work require you to work fast? (4). The answering format of the items was $1=$ very rarely/never to $5=$ very often/ constantly.

ISTA scale on task uncertainty (Cronbach's alpha $=.76$ ) was assessed as follows: From how many people do you receive instructions on a regular basis? (1). The answering format for the first item was $1=$ from no supervisor to $5=$ from three or four supervisors. Item two to four asked for the frequency of unclear work situations: How often do you receive unclear instructions? (2); How often do you receive contradictory instructions from different supervisors? (3); In the course of your work 
activity, how often do you have to make decisions where the necessary information is unavailable? (4), and for the last three items it was $1=$ very rarely/never to $5=$ very often/constantly.

Conscientiousness. Conscientiousness was part of the fivefactor model of personality (McCrae \& John, 1992; Costa \& McCrae, 1985). The five-factor model questionnaire we used is based on an adjective rating list developed by Ostendorf and colleagues (Ostendorf, 1990; Ostendorf \& Angleitner, 1992). The adjective rating list has been reduced by Schallberger and Venetz (1999), who demonstrated that a version with a shorter questionnaire is satisfactory in terms of factorial structure and internal consistencies of scales. Conscientiousness scales each consist of bipolar items on a six-point scale, with each pole ranging from "very" (1 and 6$)$ and "quite" (2 and 5), to "rather" (3 and 4). Conscientiousness included six items (meticulous vs. imprecise [recoded], careless vs. conscientious, regular vs. disorderly [recoded], inaccurate vs. thorough, unthoughtful vs. proper, hard-working vs. lazy [r]). Reliability coefficients (Cronbach's alpha $=.86$ ) were good.

Cognitive failure. The Workplace Cognitive Failure Scale (WCFS: Wallace \& Chen, 2005) consisted of fifteen items with a five-point Likert response format, asking for the frequency of cognitive failure at work (for example, "Forget important telephone numbers", "Do not focus your full attention on work activities", and "Say things to others that you did not mean to say"). The German version of the questionnaire was used (Elfering et al., 2011). The internal consistency of the subscales memory, attention, and action were satisfactory (Cronbach's alpha $=.71, .83, .83)$.

Risky behavior at sports and sport injuries. In pretests items of the new scale were validated. The goal was to cover the most common facets of stress-related behaviour during sports that depends on cognitive resources but are not primarily emotion driven. After pretest only items that showed no floor effects were included. Further items that were not included all address preparations before sports started ("No or only short warm-up","Forgot to do stretching" "Started immediately with sports","Arrived too late","Changed clothes in a hurry") while the three items that were included addressed behavior during sports. Three items asked for the frequency of risk taking, and uncareful and unaware behaviour during sports after work $($ Cronbach's alpha $=.66)$. The first item was "How often in the last four weeks have you taken high risks at sports after work?" The second item was "How often in the last four weeks have you been uncareful at sports after work?" And the third item was "How often in the last four weeks have you noticed yourself being unaware of others at sports after work?" Six response options ranged from $1=$ never to $6=$ very often. The types of sport injuries that were assessed were not too specific but common and comparable across various types of sports. Thus we asked about musculoskeletal injuries in the last four weeks: "In the last four weeks, did you suffer (a) a pulled muscle, (b) an overstretched tendon, or (c) a contusion that was not caused by others (like a rival or a teammate)? The response options were "yes" (1) or "no" $(0)$. Thus, the sum score of injury in the last four weeks could range from zero to three. More information on the preliminary instrument can be obtained from the author(s).

\section{Data Analysis}

Structural equation modelling with AMOS 16.0 was used (a) to test a measurement model of all constructs involved in the mediation hypothesis and (b) to model the latent path structure of the hypothesised mediation model. Unless an indicator is a near-perfect measure of the latent variable, several indicators are needed to represent it. Preferably, these are subscales, as in mental work load that was measured with ISTA subscales as indicators (performance constraints, time pressure, and task uncertainty). The latent variable of work cognitive failures included three indicators with the subscales memory, attention, and action. For the measurement modelling of conscientiousness we used the parcelling method (Kelloway, 1996). Conscientiousness was broken into three parcels with two items each. The three manifest indicators for risky behavior at sport after work were included the as indicators. The mediation hypothesis was tested with ina bootstrap test of the indirect effects. Preacher and Hayes (2008) propose bootstrapping because it is more robust in small samples than other approaches to test mediation. Bootstrapping, a nonparametric resampling procedure, is an additional method advocated for testing mediation that does not impose the assumption of normality in the sampling distribution. Bootstrapping is a computationally intensive method that involves repeatedly sampling from the data set and estimating the indirect effect in each resampled data set. By repeating this process thousands of times, an empirical approximation of the sampling distribution of the indirect (mediation) path is built and used to construct confidence intervals for the indirect effect.

A test of a hypothesised structural equation model should also include a test of a plausible alternative model. A plausible alternative approach is the person-oriented accident-prone person model which postulates the opposite direction of causality, which is to say that individual traits like conscientiousness induce stable individual differences in action regulation. The idea of an accident-prone person "implies that, irrespective of environment, that individual is more likely at all times to incur an accident than his colleagues even though exposed to equal risk, and that this is due to some characteristic or summation of characteristics associated with corporeal dexterity, sensorimotor skill, personality, or higher conative or cognitive function" (Cresswell \& Frogatt, 1962, p.152). According to the accidentprone person model, individual traits like conscientiousness induce stable individual differences in cognitive failures. Cog- 
nitive failure induces work stressors: increased time pressure at work, for instance, is produced by forgetting of tasks and deadlines. Work demands might then mediate the effects of cognitive failures on risky sport behavior. The accident-prone person model is compared to the hypothesised mediation model. A insignificant mediation and significantly worse fit of data in the alternative accident-prone person model than in the hypothesised mediation model would increase the plausibility of the latter. Because of the directional hypothesis, alpha level was one-tailed (Wonnacott \& Wonnacott, 1984).

\section{Results}

Recent musculoskeletal injuries that were not caused by others were reported by half of the sample $(48.1 \%)$. In the last four weeks $17 \%$ reported the occurrence of two $(11.6 \%)$ or even three types of musculoskeletal injuries (5.4\%).

Table 1 shows the mean values and standard deviation of the study variables. Performance constraints at work were moderate. Mean level of time pressure at work was high and task uncertainty was less common. Mean level of the cognitive failure subscales memory, attention, and action were compara- bly low. Mean levels of memory and attention subscales found in this study (memory: 1.97, attention: 2.13 ) were comparable to values of 323 participants of various occupations reported by Wallace and Chen in 2005 (memory: 2.06, attention: 2.04). The mean level in the action subscale was 1.63 and seemed to be lower than the level reported by Wallace and Chen (2.31). Conscientiousness was high, while careless action at sports after work was comparable to the frequency of being unaware of others, and both were less common than risk taking.

Table 2 shows correlations among study variables. Performance constraints, time pressure, and task uncertainty were positively related. Higher performance constraints were associated with more frequent cognitive failure in both memory and action. Higher levels of time pressure at work corresponded to more frequent cognitive failure in action. Task uncertainty was positively associated with all three cognitive failure subscales. Musculoskeletal sport injuries correlated positively with subscales of cognitive failures and with risk behaviours at sports. Higher conscientiousness was related to fewer performance constraints and fewer cognitive failures in attention and action.

Table 1

Descriptive statistics and internal consistency (Cronbach's alpha) for all study variables.

\begin{tabular}{|c|c|c|c|c|c|}
\hline Variables & Items & Range & $M$ & $S D$ & Cronbach's Alpha \\
\hline ISTA: Performance Constraints & 4 & $1-5$ & 2.10 & 0.71 & .74 \\
\hline ISTA: Time pressure & 4 & $1-5$ & 3.35 & 0.78 & .80 \\
\hline ISTA: Task uncertainty & 4 & $1-5$ & 2.57 & 0.73 & .76 \\
\hline WCFS: Memory & 5 & $1-5$ & 1.97 & 0.63 & .71 \\
\hline WCFS: Attention & 5 & $1-5$ & 2.13 & 0.56 & .83 \\
\hline WCFS: Action & 5 & $1-5$ & 1.63 & 0.53 & .83 \\
\hline Sport: Risk taking & 1 & $1-5$ & 3.00 & 1.24 & n.a. \\
\hline Sport: Unaware of others & 1 & $1-5$ & 2.17 & 1.03 & n.a. \\
\hline Athletic injuries & 1 & Number & 0.71 & 0.88 & n.a. \\
\hline Conscientiousness & 6 & $1-6$ & 4.47 & 0.78 & .86 \\
\hline $\operatorname{Sex}(1=m, 2=f)$ & 1 & $1-2$ & n.a. & n.a. & n.a. \\
\hline Age & 1 & Number & 30.48 & 11.00 & n.a. \\
\hline
\end{tabular}

Note: n.a. $=$ not applicable.

Table 2

Intercorrelations of all study variables.

\begin{tabular}{|c|c|c|c|c|c|c|c|c|c|c|c|c|}
\hline Variables & 1 & 2 & 3 & 4 & 5 & 6 & 7 & 8 & 9 & 10 & 11 & 12 \\
\hline \multicolumn{13}{|c|}{ 1. ISTA: Performance Constraints } \\
\hline 2. ISTA: Time pressure & $.19^{*}$ & & & & & & & & & & & \\
\hline 3. ISTA: Task uncertainty & $.22 * *$ & $.36^{* * *}$ & & & & & & & & & & \\
\hline 4. WCFS: Memory & $.18^{*}$ & .10 & $.21 * *$ & & & & & & & & & \\
\hline 5. WCFS: Attention & .04 & -.04 & $.32 * * *$ & $.51 * * *$ & & & & & & & & \\
\hline 6. WCFS: Action & $.17 *$ & $.21^{*}$ & $.21^{* *}$ & $.54 * * *$ & $.57 * * *$ & & & & & & & \\
\hline 7. Sport: Careless & $.21 * *$ & .14 & .12 & $.32 * * *$ & $.43 * * *$ & $.32 * * *$ & & & & & & \\
\hline 8. Sport: Risk taking & .06 & .05 & $.16^{*}$ & $.20 *$ & $.22 * *$ & .10 & $.32 * * *$ & & & & & \\
\hline 9. Sport: Unaware of others & $.17^{*}$ & -.06 & $.19 *$ & $.43 * * *$ & $.40^{* * *}$ & $.41 * * *$ & $.48^{* * *}$ & $.41 * * *$ & & & & \\
\hline 10. Athletic injuries & .08 & .08 & .01 & $.34 * * *$ & $.17^{*}$ & $.19^{*}$ & $.32 * * *$ & $.15^{*}$ & $.25 * *$ & & & \\
\hline 11. Conscientiousness & $-.21 * *$ & -.01 & -.07 & -.08 & $-.21 * *$ & $-.17 *$ & -.10 & -.08 & -.11 & .07 & & \\
\hline 12. $\operatorname{Sex}(1=m, 2=f)$ & -.06 & -.11 & $-.19 * *$ & -.07 & -.05 & -.04 & .13 & -.09 & -.06 & .09 & -.09 & \\
\hline 13. Age & -.04 & .09 & .03 & $-.17 *$ & $-.20 *$ & $-.15^{*}$ & $-.20 *$ & $-.25 * *$ & $-.15^{*}$ & -.12 & .12 & $-.24 * *$ \\
\hline
\end{tabular}

Note: $N=129 .{ }^{*} p<.05, * * p<.01, * * * p<.001$, one-tailed. 
Table 3

Structural equation models fit to empirical data.

\begin{tabular}{|c|c|c|c|c|c|c|c|c|c|}
\hline Models & $\chi^{2}$ & $d f$ & $\chi^{2} / d f$ & $p$ & $G F I$ & $A G F I$ & $C F I$ & RMSEA & $A I C$ \\
\hline 1. Independence model & 674.24 & 78 & 8.64 & .00 & .55 & .48 & 0 & .24 & 700.24 \\
\hline 2. Saturated model & 0 & 0 & 0 & - & 1.00 & - & 1.00 & - & 182.00 \\
\hline 3. Measurement model & 41.09 & 56 & 0.73 & .93 & .97 & .96 & 1.00 & .00 & 111.09 \\
\hline 4. Hypothesised mediation model & 52.08 & 60 & 0.87 & .76 & .97 & .95 & 1.00 & .00 & 114.08 \\
\hline 5. Alternative accident-prone person model & 47.25 & 60 & 0.79 & .88 & .97 & .95 & 1.00 & .00 & 109.25 \\
\hline
\end{tabular}

Notes: Estimation with scale-free least square. The models are as follows: (1) Independence model = no associations between study variables were assumed; (2) Saturated model = assumes all variables were interrelated and estimates best possible fit of model variables and empirical data; (3) Measurement model $=$ all latent variables were specified and assumed to be nondirectionally interrelated; (4) Hypothesised mediation model = mediation model as shown in Figure 1; (5) Alternative accident-prone person model = trait model, conscientiousness predicts WCFS, and WCFS predicts workload that directly links to risky sport behaviour.

$\chi^{2}=$ Chi-square value indicates the minimum discrepancy between empirical covariance structures and those implied by the model; $d f=$ Degrees of freedom; $p=$ Probability of the discrepancy to differ from zero (should be nonsignificant in a good model); $\chi 2 / d f=$ Minimum discrepancy divided by its degrees of freedom as an indicator of fit; $p=\mathrm{p}$-value of minimum discrepancy divided by its degrees of freedom, which should be nonsignificant; $G F I=$ Goodness of fit index; $A G F I=$ Adjusted goodness of fit index; $C F I=$ Comparative fit index; RMSEA = Root mean square error of approximation, a measure of fit that takes into account population moments rather than sample moments; $A I C=$ Aikake information criterion, which should be as low as possible. A nonsignificant $\chi 2, G F I$ values over $.90, A G F I$ values over .85 , and $C F I$ higher than .90 in the mediation model reflect acceptable fit between the model and the data (Schermelleh-Engel et al., 2003). RMSEA value of .06 reflects a satisfactory fit of the model (Schermelleh-Engel et al., 2003). The comparably low Aikake information criterion attests to the parsimonious informative modelling in the hypothesised mediation model.

Sex was significantly related only with task uncertainty at work, indicating women to report more task uncertainty. Older Participants reported fewer cognitive failures and less frequent risky behaviours at sports.

Table 3 shows the results to the tests of the structural equation model, including several indicators of model fit and, in the notes, a comment to explain when fit indices can be considered to represent a good model fit. A model that assumes independency (zero correlations) between manifest variables and latent variables has a very poor fit and thus did not represent the data at all. In contrast, a saturated model that estimates all relations between variables reached maximal fit, and both independence model and saturated model provide a frame of reference for specific model tests. Hypothesis testing started with a test of the measurement model. The measurement model included mental work load, work-related cognitive failure, conscientiousness, and risky sport behaviour modelled as latent variables with three manifest indicator variables each. Thus, every latent variable represented a confirmatory factor analysis, and associations between latent variables were non-directional. The measurement model represented the empirical data well (CFI $=1.00 ; R M S E A=.00)$, so the confirmatory factor analyses within the measurement model proved the hypothetical factor structure.

The hypothesised mediation model also represented the empirical data well $(C F I=1.00 ; R M S E A=.00)$. The fit was however, not as good as in the measurement model. The difference between the deviation of individual value as predicted by the model and the empirical values expressed in the $\chi 2$ values between the measurement value and the mediation model was statistically meaningful $(\Delta \chi 2(4)=10.99, p=.027)$. As hypothesised in the mediation model, directed paths from mental work load to WCFS $(\beta=.41, p<.01)$ were significant, and the path from consciousness to WCFS was also significant $(\beta=-.23$, $p<.05)$. The path from WCFS to risky sport behaviour after work was significant $(\beta=.69, p<.001)$. The test of indirect effects using the bootstrapping approach within AMOS resulted in significant indirect effect for the mental work load: -> WCFS $->$ risky sport behaviour after work - path $(\beta=.28$, CI90\% $.11-.50)$. The test of the second indirect resulted in significant indirect effect for the conscientiousness: -> WCFS -> risky sport behaviour after work - path $(\beta=-.13$, CI90\% -.01 - .26). Hypothesised mediation was therefore significant in the model. The hypothesised model of mediation represented the empirical data well (Figure 1); however, a meaningful alternative model might be equally good or even better. Hence, the hypothesised model should be compared to a plausible alternative model. The view of Wallace and Chen (2005) on cognitive failure as work-related was fruitful, but previous concepts viewed cognitive failure primarily as a consequence of stable individual differences in self-regulation (Broadbent et al., 1982; Reason, 1988). A plausible alternative model was the person-oriented accident-prone person model that postulated how individuals prone to cognitive failures tend to increase mental work load by themselves by forgetting tasks and deadlines, for instance, that may generate time pressure that would have been preventable otherwise. Hence, in the accident-prone person model mental work load should mediate the effects of cognitive failures on risky sport behaviour. However, this mediation was not found to be significant because the proposed key-elemental path (the final common path of factors involved in the accident-prone person model), namely the directional path from mental work load to risky sport behaviour after work was not significant ( $\beta$ $=.001, p=.99$ ). 
Figure 1

Structural equation mediation model of work-related sport injury.

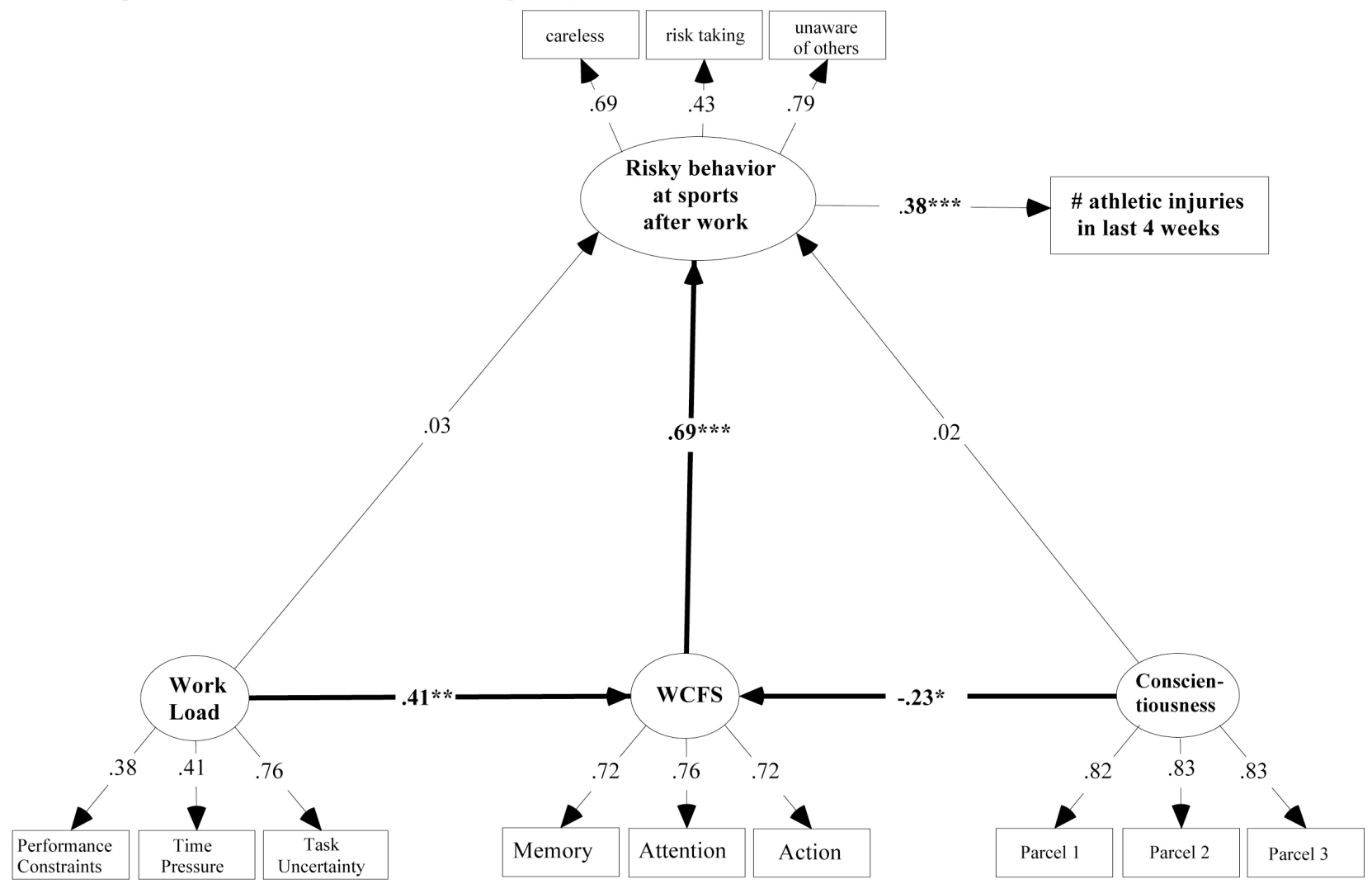

Discussion

The study showed work-related cognitive failure to mediate effects of work load on risky sport behaviour. Moreover, an alternative trait-based accident-prone person model that solely centred on individual differences in cognitive failures to account for both work load and risky sport behaviour did not receive empirical support. Nevertheless, the support for the mediation model that modelled both a work-related as well as a trait-related indirect path to risky sport behaviour confirmed the importance of individual differences in cognitive self-regulation.

The confirmed mediation in the hypothesised model and its association with musculoskeletal sport injuries might not be that impressive in terms of strengths of associations and the evidence for the positive effects of sport activities (Sonnentag \& Jelden, 2009). However, against a view of sport accidents as complex events and their multifactor causation (Kleinert, 2002), and against the background of high incidence of sport injuries in Switzerland and their increase in the last decade (from 281,000 in 2000 to 315,000 in 2009: BFU, 2011), the results are meaningful. Noteworthy, costs of sport injury include direct costs from medical treatment and indirect costs as days off work but sport injuries also restrict positive effects from sport activities and sport injuries cause further distress (Heil, 1993).
Based on the action-regulation deduced path of mental work load on cognitive failure, the working hypothesis for future research is that mental work load depleted cognitive resources and induced a change toward more parsimonious action regulation at sports after work that afforded less cognitive resources but increased risky behaviour. While cognitive errors increased in this more resource-economic mode of action regulation, cognitive errors were negatively related with attention to environmental demands, and to behaviour of rivals and teammates. Recent experimental evidence showed cognitive failure to increase anti-saccadic latencies in an anti-saccade task, a widely used tool to measure attentional control (Berggren, Hutton \& Derakhshan, 2011).

Lack of attention may also worsen postural control. Laboratory experiments showed that postural control is worse when individuals simultaneously engage in another cognitive task. Deficits in attention regulation were recently shown to mediate the constrictive effects of sleep deprivation on postural control (Robillard, Prince, Boissonneault, Filipini \& Carrier, 2011). Undertaking a cognitively demanding task (a Stroop Task, for example) and simultaneously maintaining postural balance led to a loss in balance performance in the middle-aged workforce (Granacher et al., 2011). Both postural and attentional control are thought to rely on the same limited attentional resources (Kahneman, 1973; Woollacott \& Shumway-Cook, 2002). If 
postural control during sports after work and concurrent thinking about work tasks rely on the same attentional resources and the need for attentional resources exceeds available resources, performance in at least one task drops, which increases the risk of failure in postural control during sports. The potential link between mental work load, cognitive failure, and postural control therefore merits further investigation.

Sport injuries after work could be, in part, a cost of work, while sport activities also increase fitness as a resource that facilitates work activities and resilience to work strain (Semmer et al., 2010). Some of the sport injuries that occur in the aftermath of work may be avoidable by work-related interventions that pay off. Musculoskeletal injuries and complaints cause enormous costs to society (Wieser et al., 2011). Work-related prevention of musculoskeletal injuries and complaints therefore becomes an increasingly important goal (Elfering, 2006). Recently, the focus has shifted to primary prevention of slip, trip and fall-related injury during leisure time because of their high incidence, which has been increasing in recent years (Sommer et al., 2007). Absenteeism and presenteeism due to musculoskeletal injuries and complaints increase labour costs (Mannion et al., 2009).

In order to save mental resources, work redesign should therefore reduce task stressors, increase the number of (short) breaks - especially in the second half of the work day - and increase time control. Time control should be used to arrange tasks throughout the day. The work day should start with mentally demanding tasks, while tasks with a more routine character should be done at the end of work. In this way, such work redesign would not result in decreases in productivity (Semmer et al., 2010). An important goal should be to safeguard existing task resources given the trend for these to decrease during last decades. The increase in sport injuries over the last decade (BFU, 2011) may (in part) be due to the increase in mental work load during the same period of time. The trend toward more sustained mentally demanding work conditions was recently shown in Switzerland (Grebner et al., 2011). In Switzerland the percentage of workers who reported having to work regularly (at least $25 \%$ of their working time) at "high speed" increased from $72 \%$ in 2005 (Graf et al., 2007) to $85 \%$ in 2011 (Grebner et al., 2011). Future research should test the preliminary results and spend more time on analysis of the work-leisure interface, including event sampling at work to measure day-specific cognitive load, mental fatigue and ambulatory assessment of psychophysiological indicators of cognitive strain (Klumb, Elfering \& Herre, 2009).

Another method of work-related intervention could include increasing fitness and body balance in employees (Burger, Schade, Lindner, Radlinger \& Elfering, 2012; Elfering, Arnold, Schade, Burger \& Radlinger, 2013). Increasing evidence shows that impaired body balance, which is known to be an antecedent of slips, trips, and falls at and after work (Maki et al., 2011). Elfering, Grebner and Boillat (2013) report findings of work- related cognitive failure to mediate the effects of work load on impaired body balance. The problem with much of the activity training that takes place at work sites, however, is low participation rate and a lack of sustained compliance (Kaewthummanukul \& Brown, 2006). Stochastic resonance whole body vibration training (SR-WBV) was shown to be an economic exercise which requires very little effort in terms of infrastructure, time and effort from participants. Four weeks of SR-WBV increased body balance performance in a standardized test (Elfering et al., 2013), so SR-WBV during work may help to prevent sport injuries in the aftermath of work.

\section{Limitations}

First, an important limitation arises from the cross-sectional data. Preferably, the mediation should have been tested in longitudinal data. Therefore, the study needs replication: primarily, longitudinal event sampling studies would be more adequate to study the processes involved, including a deeper look into the time period between end of work and start of sport after work. Future research should also address other personality factors involved in injury risk as individual coping with stress (Grove, 1993) and external locus of control (Pargman, 1993). The current model has a focus on mental work stressors, cognitive failures as part of the cognitive stress response and risky sport behavior that depends on cognitive resources. Emotions as part of the stress response (impatience, aggression, fear) were not in focus in this study but should be included in future work. Second, bias from common source variance may have boosted correlations in this study (Semmer, Grebner \& Elfering, 2004). Employees who perceive more mental work load and higher personal levels of cognitive failure may report more risky behavior at sports after work just because of a more overt response style. Thus, further studies should refer also to other sources of data, such as insurance data, and include a large-scale representative sample to test the moderating effects of type of sport activity, type of injury, and age of workers. Another limitation is potential selection bias because the sample was not randomly obtained. Finally, a limitation of this study is that it did not differentiate between sport injuries and sport reinjuries, with psychological factors being potentially more involved in sport reinjury than in first injury (Kleinert, 2002).

However, the study also has some advantages. The participation rate of $80 \%$ was higher than in most other questionnaire studies in applied psychology (Bretschneider, 1997). In addition, the structural equation approach included mediation tests between latent variables while measurement error was excluded from analysis.

\section{Conclusion and Outlook}

Cognitive failure seems to be a promising intervening variable in process-oriented research on working conditions and sport injury. Work psychology and sport psychology should jointly use the action regulation approach to human error in stu- 
dying the work-nonwork interface more intensively in order to learn about psychological antecedents of sport injury (Nitsch, 2001). The person-oriented approach within primary prevention should include training in postural control at work (e.g. Burger et al., 2012; Elfering et al., 2013; Granacher et al., 2011).

\section{References}

1. Andersen, M. B. \& Williams, J. M. (1988). A model of stress and athletic injury: prediction and prevention. Journal of Sport \& Exercise Psychology, 10, 294-306.

2. Anderson, M. B. \& Williams, J. M. (1993). Psychological risk factors and injury prevention. In J. Heil (Ed.), Psychology of sport injury (pp. 49-57). Champaign, IL: Human Kinetics.

3. Baumann, S. (1979). Psychologische Bedingungsfaktoren von Unfällen und Verletzungen im Sportspiel [Psychological risk factors of sport accidents and sport injuries]. Leistungssport, 9, 94-103.

4. Berggren, N., Hutton, S. B. \& Derakhshan, N. (2011). The effects of self-report cognitive failures and cognitive load on antisaccade performance. Frontiers in Psychology, 2, 1-5. http://dx.doi.org/10.3389/fpsyg.2011.00280

5. BFU (2011). STATUS 2011: Statistik der Nichtberufsunfälle und des Sicherheitsniveaus in der Schweiz, Strassenverkehr, Sport, Haus und Freizeit [STATUS 2011: Statistics of nonoccupational accidents and safety in Switzerland, traffic, sports, home and leisure]. Bern: Beratungsstelle für Unfallverhütung.

6. Bluedorn, A. C., Kaufman, C. F. \& Lane, P. M. (1992). How many things do you like to do at once: An introduction to monochronic and polychronic time. Academic Management Executive, 6, 17-26. http://dx.doi.org/10.5465/ $\underline{\text { AME.1992.4274453 }}$

7. Boomsma, D. I. (1998). Genetic analysis of cognitive failures (CFQ). A study of Dutch adolescent twins and their parents. European Journal of Personality, 12, 321-30. http://dx.doi. org/10.1002/(SICI)1099-0984(1998090)12:5<321::AIDPER334>3.0.CO;2-5

8. Bretschneider, M. (1997). Die Mitarbeiterbefragung in der Kommunalverwaltung. Eine Methodenanalyse von Praxisbeispielen [Questionnaire study in municipal organizations: A -methodological analysis of samples]. Berlin: Deutsches Institut für Urbanistik.

9. Broadbent, D. E., Cooper, P. F., Fitzgerald, P. \& Parkes, K. R. (1982). The Cognitive Failures Questionnaire (CFQ) and its correlates. British Journal of Clinical Psychology, 21, 1-16. http://dx.doi.org/10.1111/j.2044-8260.1982. tb01421.x

10. Burger, C., Schade, V., Lindner, C., Radlinger, L. \& Elfering, A. (2012). Stochastic resonance training reduces musculoskeletal symptoms in metal manufacturing workers: A controlled preventive intervention study. Work, 42, 269-78.

11. Choi, B., Schnall, P. L., Yang, H., Dobson, M., Landsbergis, P., Israel, L. Karasek, R. \& Baker, D. (2010). Psycho- social working conditions and active leisure-time physical activity in middle-aged us workers. International Journal of Occupational Medicine and Environmental Health, 23, 239-253. http://dx.doi.org/10.2478/v10001-010-0029-0

12. Costa, P. T., Jr. \& McCrae, R. R. (1985). The NEO Personality Inventory Manual. Odessa: Psychological Assessment Resources.

13. Cresswell, W.L \& Frogatt, P. (1962). Accident proneness, or variable accident tendency? Journal of the Statistical and Social Inquiry Society of Ireland, 20, 152-171.

14. Day, A., Brasher, K. \& Bridger, R. S. (2012). Accident proneness re-visited: The role of job strain. Accident Analysis and Prevention, 49, 532-535. http://dx.doi.org/10.1016/j. aap.2012.03.028

15. Elfering, A. (2006). Work-related outcome assessment instruments. European Spine Journal, 15, S32-S43. http:// dx.doi.org/10.1007/s00586-005-1044-X

16. Elfering, A., Arnold, S., Schade, V., Burger, C. \& Radlinger, L. (2013). Stochastic resonance whole-body vibration, musculoskeletal symptoms and body balance: A worksite training study. Safety and Health@Work, 4, 149-155. http://dx.doi.org/10.1016/j.shaw.2013.07.002

17. Elfering, A. \& Grebner, S., 2008. Stress and Patient Safety. In J. R. B. Halbesleben (ed.), The Handbook of Stress and Burnout in Health Care (pp.173-186). Hauppauge, NY: Nova Science Publishers.

18. Elfering, A., Dubi, M. \& Semmer, N. K., 2010. Participation during major technological change and back pain. Industrial Health, 48, 370-375. http://dx.doi.org/10.2486/ indhealth.48.370

19. Elfering, A., Grebner, S. \& Boillat, C. (2013). Busy at work and absent-minded at home: Mental work load, cognitive failure and domestic falls. Swiss Journal of Psychology, 72, 219-228. http://dx.doi.org/10.1024/1421-0185/a000114

20. Elfering, A., Grebner, S. \& Dudan, A. (2011). Job characteristics in nursing and work specific cognitive failure. Safety and Health@Work, 2,1-7.

21. Elfering, A., Grebner, S., Semmer, N. K. \& Gerber, H. (2002). Time control, catecholamines and back pain among young nurses. Scandinavian Journal of Work, Environment \& Health, 28, 386-393. http://dx.doi.org/10.5271/ sjweh.690

22. Elfering, A., Grebner, S., Semmer, N. K., Kaiser-Freiburghaus, D., Lauper-Del Ponte, S. \& Witschi, I. (2005). Chronic job stressors and job control: Effects on eventrelated coping success and well-being. Journal of Occupational and Organizational Psychology, 78, 237-252. http:// dx.doi.org/10.1348/096317905X40088

23. Elfering, A., Semmer, N. K. \& Grebner, S. (2006). Work stress and patient safety: Observer-rated work stressors as predictors of characteristics of safety-related events reported by young nurses. Ergonomics, 49, 457-469. http:// dx.doi.org/10.1080/00140130600568451

24. Frese, M. \& Zapf, D. (1994). Action as the core of work 
psychology. A German approach. In H. C. Triandis, M. D. Dunnette \& L. M. Hough (Eds.), Handbook of Industrial and Organizational Psychology, Vol. 4 (pp. 271-340). Palo Alto, CA: Consulting Psychologists Press.

25. Graf, M., Pekruhl, U., Korn, K., Krieger, R., Mücke, A. \& Zölch, M. (2007). 4. Europäische Erhebung über die Arbeitsbedingungen 2005. Ausgewählte Ergebnisse aus Schweizer Perspektive [4th European study on working conditions 2005. Selected results from a Swiss perspective]. Bern, Switzerland: Staatssekretariat für Wirtschaft (Seco).

26. Granacher, U., Wick, C., Rueck, N., Esposito, C., Roth, R. \& Zahner, L. (2011). Promoting balance and strength in the middle-aged workforce. International Journal of Sports Medicine, 32, 35-44. http://dx.doi. org/10.1055/s-0030-1267214

27. Grebner, S., Berlowitz, I., Alvarado, V. \& Cassina, M. (2011). Stress-Studie 2010. Stress bei Schweizer Erwerbstätigen. Zusammenhänge zwischen Arbeitsbedingungen, Personenmerkmalen, Befinden und Gesundheit [Stress study 2010. Stress in Swiss employees. Associations between working conditions, person characteristics, wellbeing, and health]. Bern, Switzerland: Staatssekretariat für Wirtschaft (Seco).

28. Grebner, S., Elfering, A., Semmer, N., Kaiser-Probst, C. \& Schlapbach, M. L. (2004). Stressful situations at work and in private life among young workers: An event sampling approach. Social Indicators Research, 67, 11-49. http:// dx.doi.org/10.1023/B:SOCI.0000007333.96382.3a

29. Grebner, S., Semmer, N. K. \& Elfering, A. (2005). Working conditions and three types of well-being: A longitudinal study with self-report and rating data. Journal of Occupational Health Psychology, 10, 31-43. http://dx.doi. org/10.1037/1076-8998.10.1.31

30. Grebner, S., Semmer, N. K., Lo Faso, L., Gut, S., Kälin, W. \& Elfering, A. (2003). Working conditions, well-being and job-related attitudes among call centre agents. European Journal of Work and Organizational Psychology, 12, 341365. http://dx.doi.org/10.1080/13594320344000192

31. Grove, J. R. (1993). Personality and injury rehabilitation among sport performers. In D. Pargman, (Ed.), Psychological bases of sport injuries (pp.99-120). Morgantown: Fitness Information Technology.

32. Hacker, W. (2003). Action regulation theory: A practical tool for the design of modern work processes? European Journal of Work and Organizational Psychology, 12, 105130. http://dx.doi.org/10.1080/13594320344000075

33. Hacker, W. (1998). Allgemeine Arbeitspsychologie: Psychische Regulation von Arbeitstätigkeiten [General industrial psychology: Action regulation]. Bern: Huber.

34. Heil, J. (1993). Sport psychology, the athlete at risk, and the sports medicine team. In J. Heil (Ed.), Psychology of sport injury (pp. 1-13). Champaign, IL: Human Kinetics.
35. Hildebrandt, V. H., Bongers, P. M., Dul, J., van Dijk, F. J. \& Kemper, H. C. (2000). The relationship between leisure time, physical activities and musculoskeletal symptoms and disability in worker populations. International Archive of Occupational and Environmental Health, 73, 507-518. http://dx.doi.org/10.1007/s004200000167

36. Hofmann, D. A. \& Frese, M. (2011). Errors in Organizations. New York: Routledge.

37. The IPD-Work Consortium: Fransson, E. I., Heikkilä, K., Nyberg, S., Zins, T. M., Westerlund, H., Westerholm, P., Väänänen, A., Virtanen, M., Vahtera, J., Theorell, T., Suominen, S., Singh-Manoux, A., Siegrist, J., Sabia, S., Rugulies, R., Pentti, J., Oksanen, T., Nordin, M., Nielsen, M. L., Marmot, M. G., Magnusson Hanson, L. L., Madsen, I. E. H., Lunau, T., Leineweber, C., Kumari, M., Kouvonen, A., Koskinen, A., Koskenvuo, M., Knutsson, A., Kittel, F., Jöckel, K.-H., Joensuu, M., Houtman, I. L., Hooftman, W. E., Goldberg, M., Geuskens, G. A., Ferrie, J. E., Erbel, R., Dragano, N., De Bacquer, D., Clays, E., Casini, A., Burr, H., Borritz, M., Bonenfant, S., Bjorner, J. B., Alfredsson, L., Hamer, M., Batty, G. D. \& Kivimäki, M. (2012). Job strain as a risk factor for leisure-time physical inactivity: An individual-participant meta-analysis of up to 170,000 Men and Women. American Journal of Epidemiology, 176, 1078-1089. http://dx.doi.org/10.1093/aje/kws336

38. Janssen, S. P. (1991). Psychische Bedingungen für Sportunfälle und Sportverletzungen: Das Anforderungsbewältigungskonfliktmodell [Psychological conditions of sport accidents and sport injuries: The demand-coping-conflictmodel]. In Sportpsychologische Forschungsmethodik Grundlagen, Probleme, Ansätze, ed. R. Singer, pp.278-282. Köln: bps.

39. Junge, A. (2000). The influence of psychological factors on sports injuries: Review of the literature. The American Journal of Sports Medicine, 28, 10-15.

40. Kaewthummanukul, T., \& Brown, K. C. (2006). Determinants of employee participation in physical activity: critical review of the literature. American Association of Occupational Health Nurses Journal, 54, 249-261.

41. Kahneman, D. (1973). Attention and Effort. Englewood Cliffs, NJ: Prentice-Hall.

42. Kelloway, E. K. (1996). Common practices in structural equation modeling. In C. L. Cooper, I. T. Robertson (Eds.), International Review of Industrial and Organizational Psychology (pp.141-180). Chichester: Wiley.

43. Kleinert, J. (2002). Psychologische Prävention von Sportverletzungen. Beiträge zur Diagnostik, Modellbildung und Intervention [Psychological prevention of sport injuries. Contributions to diagnostics, modelling, and intervention]. Unveröffentlichte Habilitationsschrift, Deutsche Sporthochschule Köln.

44. Klumb, P. L. (1995). Cognitive failures and performance differences: validation studies of a German version of the 
cognitive failures questionnaire. Ergonomics, 38, 14561467. http://dx.doi.org/10.1080/00140139508925202

45. Klumb, P. L., Elfering, A. \& Herre, C. (2009). Ambulatory Assessment in I/O Psychology: Fruitful Examples and Methodological Issues. European Psychologist, 14, 120 131. http://dx.doi.org/10.1027/1016-9040.14.2.120

46. Kouvonen, A., Kivimäki, M., Elovainio, M., Virtanen, M., Linna, A. \& Vahtera, J. (2005). Job strain and leisure-time physical activity in female and male public sector employees. Preventive Medicine, 41, 532-539. http://dx.doi. org/10.1016/j.ypmed.2005.01.004

47. Kratzer, H. (1993). Die Erfassung der Handlungszuverlässigkeit - Eine wichtige Vorraussetzung zur Ableitung effektiver Sicherheitsunterweisungen und Trainingsmassnahmen [Measurement of action reliability - an important prerequisite in deduction of safety rules and training schedules]. In E. Rümmele (Ed.), Kognitive Repräsentationen über Unfälle und Sicherheitsunterweisungen im Sport (pp.3-12). Köln: bps.

48. Maki, B. E., Sibley, K. M., Jaglal, S. B., Bayley, M., Brooks, D., Fernie, G. R., Flint, A. J., Gage, W., Liu, B. A., McIlroy, W. E., Mihailidis, A., Perry, S. D., Popovic. M. R., Pratt, J. \& Zettel, J. L. (2011). Reducing fall risk by improving balance control: Development, evaluation and knowledgetranslation of new approaches. Journal of Safety Research, 42, 473-485. http://dx.doi.org/10.1016/j.jsr.2011.02.002

49. Mannion, A. F., Horisberger, B., Eisenring, C., Tamcan, O., Elfering, A. \& Müller, U. (2009). The association between beliefs about low back pain and work presenteeism. Journal of Occupational and Environmental Medicine, 51, 12561266. http://dx.doi.org/10.1097/JOM.0b013e3181beac69

50. McCrae, R. R. \& John, O. P. (1992). An introduction to the five-factor model and its application. Journal of Personality, 60, 175-215. http://dx.doi.org/10.1111/j.1467-6494.1992. tb00970.x

51. Mulder, G., Mulder, L. J. M., Meijman, T. F., Veldman, B. P. \& van Roon, A. M. (2000). A psychophysiological approach to working conditions. In R. W. Backs \& W. Boucsein (Eds.), Engineering Psychophysiology. Issues and Applications (pp.139-160). Mahwah, N. J.: Lawrence Erlbaum.

52. Nitsch, J. R. (2001). Handlungsfehler im Sport - Theoretische Ausgangspunkte einer Forschungskonzeption [Action regulation errors in sports - theoretical starting points of a research conception]. In D. Hackfort (Ed.), Handlungspsychologische Forschung für die Theorie und Praxis der Sportpsychologie (pp. 65-124). Köln: bps.

53. Nitsch, J. R. (2004). Die handlungstheoretische Perspective: ein Rahmenkonzept für die sportpsychologische Forschung und Intervention [The action-theoretical perspective: A frame of reference for research and application in sport psychology]. Zeitschrift für Sportpsychologie, 11, 10-23. http://dx.doi.org/10.1026/1612-5010.11.1.10

54. Oesterreich, R. \& Volpert, W. (1986). Task analysis of action regulation theory. Economic and Industrial Democracy, 7, 503-527. http://dx.doi.org/10.1177/0143831X8674005

55. Ostendorf, F. (1990). Sprache und Persönlichkeitsstruktur: Zur Validität des Fünf-Faktoren-Modells der Persönlichkeit [Language and personality structure: The validity of the five-factor model of personality]. Regensburg: Roderer.

56. Ostendorf, F. \& Angleitner, A. (1992). On the generality and comprehensiveness of the Five-Factor model of personality. Evidence for five robust factors in questionnaire data. In G. V. Caprara \& G. L. van Heck (Eds.), Modern personality psychology. Critical reviews and new directions (pp.73-109). New York: Harvester Wheatsheaf.

57. Pargman, D. (Ed.) (1993). Psychological bases of sport injuries. Morgantown: Fitness Information Technology.

58. Preacher, K. J. \& Hayes, A. F. (2008). Asymptotic and resampling strategies for assessing and comparing indirect effects in multiple mediator models. Behavior Research Methods, 40, 879-891. http://dx.doi.org/10.3758/ BRM.40.3.879

59. Reason, J. (1990). Human Error. Cambridge: Cambridge University Press. http://dx.doi.org/10.1017/ CBO9781139062367

60. Reason, J. (1988). Stress and cognitive failure. In S. Fisher \& J. Reason (Ed.), Handbook of Life Stress, Cognition, and Health (pp.405-421). New York: Wiley.

61. Robillard, R., Prince, F., Boissonneault, M., Filipini, D. \& Carrier, J. (2011). Effects of increased homeostatic sleep pressure on postural control and their modulation by attentional resources. Clinical Neurophysiology, 122, 17711778. http://dx.doi.org/10.1016/j.clinph.2011.02.010

62. Rümmele, E. (1989). Überlegungen zur Struktur von Sportunfällen [Considerations on the structure of sport injuries]. In E. Rümmele \& D. Kayser (Ed.), Sicherheit im SportEine Herausforderung für die Sportwissenschaft (pp.1533). Köln: Sport und Buch Strauss.

63. Schallberger, U. \& Venetz, M. (1999). Kurzversionen des MRS-Inventars von Ostendorf (1990) zur Erfassung der fünf ,grossen“ Persönlichkeitsfaktoren [Brief versions of Ostendorf's MRS inventory for the assessment of the BigFive personality factors]. Universität Zürich: Berichte aus der Abteilung Angewandte Psychologie, 30, 1-51.

64. Schermelleh-Engel, K., Moosbrugger, H. \& Müller, H. (2003). Evaluating the fit of structural equation models: test of significance and descriptive goodness-of-fit measures. Methods of Psychological Research Online, 8, 23-74.

65. Seiler, R. (1995). Kognitive Organisation von Bewegungshandlungen. Empirische Untersuchungen mit dem Inversionsprinzip [Cognitive organisation of intended movement. Empirical studies using the inversion principle]. Sankt Augustin: Academia.

66. Semmer, N. (1984). Streßbezogene Tätigkeitsanalyse. [Stress-related job analysis]. Weinheim: Beltz.

67. Semmer, N., Grebner, S. \& Elfering, A. (2010). Psychis- 
che Kosten von Arbeit. [Psychological costs of work]. In: Enzyklopädie der Psychologie. Band: Arbeitspsychologie, Bd. D-III-1, pp.325-370. Göttingen: Hogrefe.

68. Semmer, N. K., Grebner, S. \& Elfering, A. (2004). Beyond self-report: Using observational, physiological, and eventbased measures in research on occupational stress. In P. L. Perrewé \& D. C. Ganster (Eds.), Emotional and Physiological Processes and Positive Intervention Strategies. Research in Occupational Stress and Well-being, Vol. 3. (pp. 205-263) Amsterdam: JAI. http://dx.doi.org/10.1016/ $\underline{\mathrm{S} 1479-3555(03) 03006-3}$

69. Semmer, N., Zapf, D. \& Dunckel, H., (1995). Assessing stress at work: A framework and an instrument. In O. Svane \& C. Johansen (Eds.), Work and Health - Scientific Basis of Progress in the Working Environment (pp.105-113). Luxembourg: Office for Official Publications of the European Communities.

70. Semmer, N., Zapf, D. \& Greif, S. (1996). 'Shared job strain'. A new approach for assessing the validity of job stress measurements. Journal of Occupational and Organizational Psychology, 69, 293-310.

71. Sonnentag, S. \& Bayer, U.-V. (2005). Switching off mentally: Predictors and consequences of psychological detachment from work during off-job time. Journal of Occupational Health Psychology, 10, 393-414. http://dx.doi. org/10.1037/1076-8998.10.4.393

72. Sommer, H., Brügger, O., Lieb, C. \& Niemann, S. (2007). Volkswirtschaftliche Kosten der Nichtberufsunfälle in der Schweiz: Strassenverkehr, Sport, Haus und Freizeit [National expenditure on nonoccupational accidents in Switzerland: Traffic, sport, home and leisure]. Beratungsstelle für Unfallverhütung: Report 58. Bern: Beratungsstelle für Unfallverhütung.

73. Sonnentag, S. \& Jelden, S. (2009). Job stressors and the pursuit of sport activities: A day-level perspective. Journal of Occupational Health Psychology, 14, 165-181. http:// dx.doi.org/10.1037/a0014953

74. Tsutsumi, A., Kayaba, K., Yoshimura, M., Sawada, M., Ishikawa, S., Sakai, K., Gotoh, T., Nago, N. \& Jichi Medical School Cohort Study Group (2003). Association between job characteristics and health behaviors in Japanese rural workers. International Journal of Behavioral Medicine, 10, 125-142. http://dx.doi.org/10.1207/ S15327558IJBM1002_03
75. Wallace, J. C. \& Chen, G. (2005). Development and validation of a work-specific measure of cognitive failure: Implications for occupational safety. Journal of Occupational and Organizational Psychology, 78, 615-632. http://dx.doi. org/10.1348/096317905X37442

76. Wieser, S., Horisberger, B., Schmidhauser, S., Eisenring, C., Brügger, U., Ruckstuhl, A., Dietrich, J., Mannion, A., Elfering, A., Tamcan, Ö. \& Müller, U. (2011). Cost of Low Back Pain in Switzerland in 2005. European Journal of Health Economics, 12, 455-467. http://dx.doi.org/10.1007/ s10198-010-0258-y

77. Williams, J. M. (1996). Stress, coping resources, and injury risk. International Journal of Stress Management, 3, 209221. http://dx.doi.org/10.1007/BF01857684

78. Williams, J. M. \& Andersen, M. B. (2007). Psychosocial antecedents of sport injury and interventions for risk reduction. In G. Tenenbaum \& R.C. Eklund (Eds.), Handbook of Sport Psychology (pp. 379-403). New York: John Wiley \& Sons, Inc.

79. Williams, J. M. \& Roepke, N. (1993). Psychology of injury and injury rehabilitation. In R. N. Singer, M. Murphey \& L. K. Tennant (Eds.), Handbook of research on sport psychology (pp. 815-839). New York: Macmillan Publishing Company.

80. Wonnacott, T. H. \& Wonnacott, R. J. (1984). Introductory Statistics for Business and Economics. New York: Wiley.

81. Woollacott, M. \& Shumway-Cook, A. (2002). Attention and the control of posture and gait: a review of an emerging area of research. Gait and Posture, 16, 1-14. http://dx.doi. org/10.1016/S0966-6362(01)00156-4

Received 23 August 2013 Received in revised form 30 January 2014 Accepted 1 February 2014 